\title{
Brief Report \\ Soluble Urokinase Plasminogen Activator Receptor Levels Correlation with Other Inflammatory Factors in Prognosis of Disability and Death in Patients with Ischemic Stroke
}

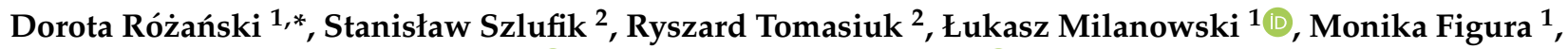 \\ Kamila Saramak ${ }^{1}$, Piotr Myrcha ${ }^{3,4}$ (D) and Dariusz Koziorowski ${ }^{1}$ (D)
}

check for updates

Citation: Różański, D.; Szlufik, S.; Tomasiuk, R.; Milanowski, Ł.; Figura, M.; Saramak, K.; Myrcha, P.; Koziorowski, D. Soluble Urokinase Plasminogen Activator Receptor Levels Correlation with Other Inflammatory Factors in Prognosis of Disability and Death in Patients with Ischemic Stroke. Brain Sci. 2022, 12,

39. https://doi.org/10.3390/ brainsci12010039

Academic Editors:

Vasileios Papavasileiou and Ana Maria Bugă

Received: 23 November 2021 Accepted: 24 December 2021 Published: 28 December 2021

Publisher's Note: MDPI stays neutral with regard to jurisdictional claims in published maps and institutional affiliations.

Copyright: (C) 2021 by the authors. Licensee MDPI, Basel, Switzerland. This article is an open access article distributed under the terms and conditions of the Creative Commons Attribution (CC BY) license (https:// creativecommons.org/licenses/by/ $4.0 /)$.
1 Department of Neurology, Faculty of Health Sciences, Medical University of Warsaw, 02-091 Warsaw, Poland; lukasz.milanowski@wum.edu.pl (Ł.M.); monika.figura@wum.edu.pl (M.F.); kamilasaramak@gmail.com (K.S.); dkoziorowski@wum.edu.pl (D.K.)

2 Faculty of Medical Sciences and Health Sciences, Kazimierz Pulaski University of Technology and Humanities, 26-600 Radom, Poland; sszlufik@wum.edu.pl (S.S.); r.tomasiuk@wp.pl (R.T.)

3 Department of General and Vascular Surgery, Faculty of Medicine, Medical University of Warsaw, 02-091 Warsaw, Poland; piotr.myrcha@wum.edu.pl

4 Department of General, Vascular and Oncological Surgery, Masovian Brodnowski Hospital, 03-242 Warsaw, Poland

* Correspondence: dvd@mail.com; Tel.: +48-22-326-5744; Fax: +48-22-326-5815

\begin{abstract}
Soluble urokinase plasminogen activator receptor (suPAR) is an inflammatory biomarker elevated in cardiovascular diseases. The aim of this 3-year follow-up prospective study was to evaluate suPAR levels in patients with a first ischemic stroke in correlation with CRP, PCT, NTproCNP and endothelin 1-21 and to investigate the impact of suPAR on the outcome. Fifty-one patients (mean age 73.7 $+=11.9$ years, 26 female and 25 male) were included. Samples were collected on the first (suPAR 1), third (suPAR 3) and seventh days after stroke onset (suPAR 7). Plasma samples were analyzed using ELISA. A phone interview was conducted to collect follow-up information after 24 and 36 months (modified Rankin Scale, mRS). A positive correlation between suPAR levels and other inflammatory biomarkers (except endothelin 3) was observed. A positive correlation between suPAR 3 and $\mathrm{mRS}$ score at 24 months was observed $(p=0.042)$. The logistic regression model revealed no significant effect of suPAR on death occurrence in the first 24 months: suPAR $1(p=0.8794)$, suPAR $3(p=0.2757)$, and suPAR 7 ( $p=0.3652)$. The suPAR level is a potential inflammatory marker in ischemic stroke, and there is a correlation with other markers. There is no major impact on mortality. However, the suPAR level is associated with a degree of disability or dependence in daily activities 2 years after a stroke.
\end{abstract}

Keywords: ischemic stroke; suPAR; cardiovascular disease; inflammation; atherosclerosis; carotid artery disease

\section{Introduction}

Over the last few decades, increased evidence has suggested that chronic inflammation plays a major role in the development of atherosclerosis [1,2]. Therefore, several population-based studies have investigated the relationship between a number of inflammatory biomarkers and cardiovascular disease (CVD), including ischemic stroke [3-5].

Soluble urokinase plasminogen activator receptor (suPAR) is an emerging biomarker which is thought to reflect the activation of the immune system [6]. It is a soluble bioactive form of urokinase plasminogen activator receptor (uPAR, CD 87), which is a membrane protein located on various types of cells, including monocytes, macrophages, activated T-lymphocytes, endothelial and smooth muscle cells [7-13], all of which are involved in atherosclerosis [14]. Not only is the uPA-uPAR system known to be involved in fibrinolysis through the plasminogen activating pathway, but it also regulates angiogenesis, cell 
proliferation, migration, adhesion and recruitment of inflammatory cells [15-17]. Soluble UPAR is cleaved from the cell membranes and released into the circulation due to either acute or chronic inflammation $[6,18]$.

High plasma levels of suPAR were detected in patients with infectious diseases $[19,20]$ as well as several types of cancer [21-24] and are associated with poor prognosis. Lately, suPAR has gained interest as a possible risk marker for CVD, type 2 diabetes mellitus (DM2), cancer and mortality in the general population [25-27]. Elevated levels of suPAR in plasma have also been linked to subclinical organ damage and cardiovascular events, helping to predict all-cause mortality in transient ischemic attack (TIA) and ischemic stroke $[27,28]$. Few studies focused on the evaluation of suPAR levels in plasma in association with the histopathological assessment of atherosclerotic plaque morphology [26]. A study by Onatsu et al. showed that suPAR concentration was higher in patients after a stroke/TIA due to large-artery atherosclerosis compared to small-vessel disease (SVD), and that elevated plasma suPAR concentrations predicted all-cause mortality during the 5-year follow-up [29].

A study by Kiiski et al. reported that plasma suPAR is not associated with neurological outcome after subarachnoid hemorrhage, but there is a lack of publications that observe the correlation between suPAR level and outcome after ischemic stroke [30].

The aim of this 3-year follow up prospective study was to evaluate suPAR levels in patients with a first-ever ischemic stroke in correlation with established inflammatory markers-C-reactive protein (CRP), procalcitonin $(\mathrm{PCT})$, n-terminal pro c-type natriuretic peptide (NT-proCNP) and markers of endothelial damage (endothelin 1-21, NT-proCNP) and to investigate if elevated levels of suPAR are associated with the degree of disability and death in patients with ischemic stroke, assessed on a modified Rankin Scale (mRS).

\section{Materials and Methods}

\subsection{Patients}

Fifty-one patients (mean age of $73.7 \pm 11.9$ years, 26 female and 25 male) with a firstever ischemic stroke confirmed by computer tomography (CT) scan (CT GE light speed 8, layer thickness $2.5 \mathrm{~mm}$ ) and/or magnetic resonance imaging (MRI) of the brain (MRI GE Sigma excite 1.5T) were included in the study.

Patients had the following risk factors for stroke: hypertension $(40=78.43 \%)$, diabetes $(19=37.25 \%)$, hyperlipidemia $(25=49.01 \%)$, coronary artery disease $(11=21.56 \%)$, history of myocardial infarction $(7=13.72 \%)$, heart failure $(3=5.88 \%)$, atrial fibrillation $(16=31.37 \%)$, and smoking $(7=13.72 \%)$ (Table 1$)$.

Considering the risk factors for stroke and the results of neuroimaging, the patients were classified according to the TOAST classification.

The patients were treated with the standard therapy of ischemic stroke, involving thrombolytic therapy, antiplatelet therapy, anticoagulant therapy, antihypertensive treatment, treatment of heart failure, and lipid-lowering and hypoglycemic treatment (Table 1).

Patients were recruited in the Department of Neurology, Masovian Brodnowski Hospital, Warsaw, between years 2013 and 2014. Exclusion criteria included detection of hemorrhagic stroke on imaging, generalized neoplastic disease, sepsis, previous history of stroke and a second stroke during hospitalization. During hospitalization, all patients received routine treatment for the secondary prevention of stroke. A total of 9 out of 51 patients developed pneumonia, and 7 out of 51 a urinary tract infection during hospitalization. In total, 1 patient developed a gastrointestinal tract infection.

Doppler ultrasonography (DUS) of the carotid and vertebral arteries was performed to assess the presence of atherosclerotic lesion. DUS was performed according to the protocol of the Polish Ultrasound Society using the Philips HD 15 ultrasound machine with a 10-12 $\mathrm{Hz}$ linear probe. Atherosclerotic lesions in the carotid arteries were visualized in $36(70.6 \%)$ patients. Significant stenosis of internal carotid artery (greater than 50\%) was found in 15 patients $(29.4 \%)$, including occlusion in 5 patients $(9.8 \%)$. Bilateral stenoses were found in 6 patients $(11.7 \%)$. One patient underwent carotid endarterectomy without complication. 
Table 1. Demographic, epidemiological and pharmacological treatment data.

\begin{tabular}{|c|c|}
\hline Number of Patients & 51 \\
\hline Males & 25 \\
\hline Age: Mean (SD) & $73.7(11.9)$ \\
\hline Comorbidities & $\mathrm{N}$ of patients $(\%)$ \\
\hline Hypertension & $40(78.4)$ \\
\hline Diabetes & $19(37.2)$ \\
\hline Hyperlipidemia & $25(49.0)$ \\
\hline Coronary artery disease & $11(21.6)$ \\
\hline Myocardial infarction & $7(13.7)$ \\
\hline Heart failure & $3(5.9)$ \\
\hline Atrial fibrillation & $16(31.3)$ \\
\hline Smoking & $7(13.7 \%)$ \\
\hline \multicolumn{2}{|l|}{ Pharmacological treatment } \\
\hline Thrombolytic therapy & $7(13.7)$ \\
\hline \multicolumn{2}{|l|}{ Antiplatelet therapy } \\
\hline ASA $150 \mathrm{mg}$ & $28(54.9)$ \\
\hline ASA $75 \mathrm{mg}$ & $13(25.5)$ \\
\hline ASA + Clopidogrel & $1(2.0)$ \\
\hline Clopidogrel & $1(2.0)$ \\
\hline \multicolumn{2}{|l|}{ Anticoagulant therapy } \\
\hline Enoxaparin & $15(29.4)$ \\
\hline Dabigatran & $4(7.8)$ \\
\hline \multicolumn{2}{|c|}{ Antihypertensive/heart failure treatment } \\
\hline Perindopril & $4(7.8)$ \\
\hline Ramipril & $7(13.7)$ \\
\hline Enalapril & $20(39.2)$ \\
\hline Quinapril & $1(2.0)$ \\
\hline Valsartan HCT & $1(2.0)$ \\
\hline Amiloride HCT & $1(2.0)$ \\
\hline Cilazapril HCT & $1(2.0)$ \\
\hline Metoprolol & $8(15.7)$ \\
\hline Bisoprolol & $15(29.4)$ \\
\hline Carvedilol & $1(2.0)$ \\
\hline Amlodipine & $13(25.5)$ \\
\hline Nitrendipine & $1(2.0)$ \\
\hline Lacidipine & $1(2.0)$ \\
\hline Torasemide & $2(3.9)$ \\
\hline Indapamide & $9(17.4)$ \\
\hline Spironolactone & $4(7.8)$ \\
\hline \multicolumn{2}{|l|}{ Lipid-lowering treatment } \\
\hline Simvastatin & $28(54.9)$ \\
\hline Atorvastatin & $4(7.8)$ \\
\hline Rosuvastatin & $1(2.0)$ \\
\hline Fenofibrate & $2(3.9)$ \\
\hline \multicolumn{2}{|l|}{ Hypoglycemic treatment } \\
\hline Metformin & $8(15.7)$ \\
\hline Glimepiride & $4(7.8)$ \\
\hline Insulin & $11(21.6)$ \\
\hline
\end{tabular}

ASA—acetylsalicylic acid.

Twenty-four-hour Holter electrocardiograph (ECG) monitoring and/or ECG examination were performed to detect atrial fibrillation and other cardiac arrhythmias. A detailed medical history of each patient was collected. In addition to specific inflammation biomarkers, lipid profile, renal function parameters, fasting glucose measurement and hematological parameters were assessed. 
The type of ischemic stroke was assessed according to the TOAST classification [31]. The etiology according to TOAST classification included cardioembolism in 13 patients $(26 \%)$, large-artery atherosclerosis in 16 patients (32\%), small-vessel disease in 8 patients $(16 \%)$. Thirteen patients $(26 \%)$ had cryptogenic stroke with unidentified cause.

After 24 months and 36 months from discharge, the patients or their relatives were contacted by phone (K.S., D.R.) and evaluated with the mRS. Information was gathered about follow-up end points, recurrent strokes, level of disability and death.

All participants provided informed signed consent for participation in the study. The study was approved by the Ethics Review Board of Medical University of Warsaw (KB/211/2013).

\subsection{Biochemical Measurements}

Blood samples were collected on the first (suPAR1), third (suPAR3) and seventh (suPAR7) days after stroke onset. After collection, the samples were centrifuged and immediately frozen to -20 degrees Celsius. Apart suPAR concentration the plasma samples were also analyzed on the first, third and sevenths days after stroke onset for CRP, PCT, endothelin and NT-proCNP plasma levels using enzyme-linked immunosorbent assay (ELISA).

Serum cytokines were measured using the fluorokine ${ }^{\circledR}$ MAP cytokine multiplex kit and the LuminexTM 100 Platform. Microglobules marked fluorescently with specific antibodies were positioned along with standards and serum samples examined in pits. The serum cytokines were incubated with antibodies. Afterwards, biotin conjugated antibodies were added to combine with antibody-linked cytokines. After subsequent rinsing, streptavidin$\mathrm{PE}$ conjugate was infused to connect with biotin and to emit fluorescent signal. After one more rinsing, to remove excess streptavidin, micromolecules were placed in a buffer. The 2-laser analysis of the buffer was performed on the LuminexTM 100 Platform software in accordance with to the procedures supplied by the manufacturer.

\subsection{Statistics}

All statistical analyses were performed with Statistica 13. Normality of distribution was assessed using the Shapiro-Wilk test. Continuous variables are presented as average and standard deviations. Categorical variables are presented as percentages. Correlation with other inflammatory biomarkers and with mRS score was estimated using a Pearson correlation test. A univariate, independent logistic regression model was conducted to evaluate the effect of suPAR on death occurrence in the first 24 months after ischemic stroke. What is more, the least absolute shrinkage and selection operator (LASSO) regression model was conducted to evaluate the effect of suPAR concentration on disability scales and various clinical factors. The estimation was performed based on the covariance actualization. Predictors with stable values were removed from the model. Kaplan-Meier analysis was performed to present survival rate during 36 months observation time. A value of $p \leq 0.05$ was considered significant for all tests.

\section{Results}

Biochemical data of the patients are presented in Table 2. The mean level of suPAR $1 / 2 / 3$ was $3.43 \pm 2,2 / 3.58 \pm 3,0 / 4.22 \pm 3,9 \mathrm{mg} / \mathrm{mL}$. The serum levels of suPAR $1 / 3 / 7$ were strongly correlated with the serum levels of PCT $1 / 3 / 7(\mathrm{R} 1=0.96 / \mathrm{R} 2=0.96 / \mathrm{R} 3=0.97$, $p<0.05)$ and the serum level of NT-proCNP $1 / 3 / 7(\mathrm{R} 1=0.78 / \mathrm{R} 2=0.77 / \mathrm{R} 3=0.92, p<0.05)$.

A positive correlation between suPAR 3 and $\mathrm{mRS}$ at 24 months was observed $(p=0.042)$ (Table 3). A logistic regression model revealed no significant effect of suPAR on mortality in the first 24 months (suPAR1 $(p=0.879)$, suPAR3 $(p=0.275)$, suPAR7 $(p=0.365)$. What is more, LASSO penalized regression model revealed no effect of suPAR on different clinical parameters and disability scales (Table 4 ). 
Table 2. Biochemical parameter data.

\begin{tabular}{|c|c|c|c|c|}
\hline $\begin{array}{c}\text { Biochemical } \\
\text { Parameter }\end{array}$ & & & & $p$-Value \\
\hline \multicolumn{5}{|c|}{ Day after Stroke } \\
\hline & $\begin{array}{c}\text { 1st } \\
\text { Mean (SD) }\end{array}$ & $\begin{array}{c}\text { 3rd } \\
\text { Mean (SD) }\end{array}$ & $\begin{array}{c}7 \text { th } \\
\text { Mean (SD) }\end{array}$ & \\
\hline Fibrinogen (mg/dL) & $177.44(169.41)$ & $\mathrm{N} / \mathrm{A}$ & $\mathrm{N} / \mathrm{A}$ & $\mathrm{N} / \mathrm{A}$ \\
\hline Urea $(\mathrm{mg} / \mathrm{dL})$ & $38.51(17.69)$ & $\mathrm{N} / \mathrm{A}$ & $\mathrm{N} / \mathrm{A}$ & $\mathrm{N} / \mathrm{A}$ \\
\hline Creatinine (mg/dL) & $0.94(0.23)$ & $\mathrm{N} / \mathrm{A}$ & $\mathrm{N} / \mathrm{A}$ & $\mathrm{N} / \mathrm{A}$ \\
\hline $\mathrm{HbA1C}(\%)$ & $4.85(2.90)$ & $\mathrm{N} / \mathrm{A}$ & $\mathrm{N} / \mathrm{A}$ & $\mathrm{N} / \mathrm{A}$ \\
\hline Cholesterol (mg/dL) & $180.59(52.50)$ & $\mathrm{N} / \mathrm{A}$ & $\mathrm{N} / \mathrm{A}$ & $\mathrm{N} / \mathrm{A}$ \\
\hline HDL (mg/dL) & $48.35(13.16)$ & $\mathrm{N} / \mathrm{A}$ & $\mathrm{N} / \mathrm{A}$ & $\mathrm{N} / \mathrm{A}$ \\
\hline LDL (mgdL) & $107.89(41.29)$ & $\mathrm{N} / \mathrm{A}$ & $\mathrm{N} / \mathrm{A}$ & $\mathrm{N} / \mathrm{A}$ \\
\hline $\begin{array}{l}\text { Triglycerides } \\
(\mathrm{mg} / \mathrm{dL})\end{array}$ & $128.16(103.63)$ & $\mathrm{N} / \mathrm{A}$ & $\mathrm{N} / \mathrm{A}$ & $\mathrm{N} / \mathrm{A}$ \\
\hline Glucose (mg/dL) & $131.94(52.51)$ & $\mathrm{N} / \mathrm{A}$ & $\mathrm{N} / \mathrm{A}$ & $\mathrm{N} / \mathrm{A}$ \\
\hline \multicolumn{5}{|c|}{ Inflammatory parameters } \\
\hline $\mathrm{CRP}(\mathrm{mg} / \mathrm{L})$ & $17.54(34.30)$ & $36.81(53.22)$ & $33.74(43.37)$ & $\begin{array}{l}\text { suPAR 1-3: } p=0.0044 \\
\text { suPAR 1-7: } p=0.0063\end{array}$ \\
\hline $\begin{array}{l}\text { Procalcitonin } \\
(\mathrm{ng} / \mathrm{mL})\end{array}$ & $0.31(1.23)$ & $0.33(1.08)$ & $0.39(1.94)$ & $\begin{array}{l}\text { suPAR 1-3: } p=0.261 \\
\text { suPAR 1-7: } p=0.967\end{array}$ \\
\hline suPAR (ng/mL) & $3.42(2.19)$ & $3.37(3.04)$ & $3.80(3.96)$ & $\begin{array}{c}\text { suPAR 1-3: } p=0.0865 \\
\text { suPAR 1-7: } p=0.2\end{array}$ \\
\hline $\begin{array}{l}\text { NT-proCNP } \\
(\mathrm{pg} / \mathrm{mL})\end{array}$ & $3.84(2.23)$ & $4.08(2.84)$ & $4.37(4.47)$ & $\begin{array}{l}\text { suPAR 1-3: } p=0.0977 \\
\text { suPAR 1-7: } p=0.517\end{array}$ \\
\hline Endothelin (pg/mL) & $4.03(14.58)$ & $4.08(14.53)$ & $\mathrm{N} / \mathrm{A}$ & suPAR 1-3: $p=0.59$ \\
\hline
\end{tabular}

SD—standard deviation; HbA1C-glycated hemoglobin; CRP—c-reactive protein; HDL-high-density lipoprotein; LDL-low-density lipoprotein; suPAR—soluble urokinase plasminogen activator receptor; NT-proCNP-Nterminal pro C-type natriuretic peptide.

Table 3. suPAR concentration correlation with disability scales, Pearson coefficient test $\mathrm{r}$ ( $p$-value).

\begin{tabular}{cccc}
\hline & $\begin{array}{c}\text { mRS Initial } \\
\mathbf{N}=\mathbf{5 1}(p \text {-Value })\end{array}$ & $\begin{array}{c}\text { mRS 24 } \\
\mathbf{N}=\mathbf{5 1}(p \text {-Value })\end{array}$ & $\begin{array}{c}\text { mRS 36 } \\
\mathbf{N}=\mathbf{3 5}(p \text {-Value })\end{array}$ \\
\hline suPAR 1st day & $0.13(p=0.37)$ & $0.12(p=0.4)$ & $-0.30(p=0.89)$ \\
\hline suPAR 3rd day & $0.22(p=0.13)$ & $0.29(p=0.04)$ & $-0.13(p=0.48)$ \\
\hline suPAR 7th day & $0.065(p=0.65)$ & $0.063(p=0.66)$ & $-0.02(p=0.89)$ \\
\hline
\end{tabular}

suPAR—soluble urokinase plasminogen activator receptor; mRS 24-mRS score result after 24 months; mRS score 36 -result after 36 months; $\mathrm{N}$-number of patients.

A non-significant effect was observed for suPAR on death difference between suPAR 1 and suPAR $3(p=0.108)$ and between suPAR 1 and suPAR $7(p=0.802)$.

No correlation was observed between suPAR 1, 3, and 7 and LAO and other types of strokes.

In the 3-year observation study, there were 13 recurrent strokes (12 during the 24month and an additional one during the 36-month follow-up). High mortality was observed. A total of 19 patients died (37.3\%): 16 during the first 24 months (31.4\%) and additional 3 up to 36 months (6\%). The Kaplan-Meier curve is presented in Figure 1; the interquartile range for the survival was between 6.13 and 36 months. 
Table 4. suPAR LASSO regression models with selected clinical data and disability scales.

\begin{tabular}{|c|c|c|c|c|c|c|}
\hline & $\begin{array}{c}\text { suPAR1 }- \text { Model } \\
\text { Lambda }=0.000642 \\
\% \text { Deviation }=0.734219\end{array}$ & $p$-Value & $\begin{array}{c}\text { suPAR3 }- \text { Model } \\
\text { Lambda }=0.000569 \\
\% \text { Deviation }=0.572278\end{array}$ & $p$-Value & $\begin{array}{c}\text { suPAR7 }- \text { Model } \\
\text { Lambda }=0.000640 \\
\% \text { Deviation }=0.464577\end{array}$ & $p$-Value \\
\hline & Estimates & & Estimates & & Estimates & \\
\hline Age & 0.07 & 0.07 & 0.08 & 0.99 & 0.07 & 0.86 \\
\hline $\begin{array}{l}\text { NIHSS at } \\
\text { discharge }\end{array}$ & 0.15 & 0.15 & 0.03 & 0.70 & 0.02 & 0.94 \\
\hline mRS 24 months & -0.42 & 0.39 & -0.0002 & 0.63 & 0.81 & 0.90 \\
\hline mRS 36 months & -0.97 & 0.95 & -0.79 & 0.91 & 0.07 & 0.94 \\
\hline Sex & 0.09 & 0.94 & -0.33 & 0.85 & 0.69 & 0.94 \\
\hline Hypertension & 0.27 & 0.97 & 0.33 & 0.75 & 0.55 & 0.95 \\
\hline Diabetes & 0.65 & 0.94 & 0.62 & 0.95 & -0.11 & 0.89 \\
\hline $\mathrm{AF}$ & -0.03 & 0.53 & -0.37 & 0.87 & -0.26 & 0.85 \\
\hline
\end{tabular}

NIHSS-National Institute of Health Stroke Scale. AF-atrial fibrillation.

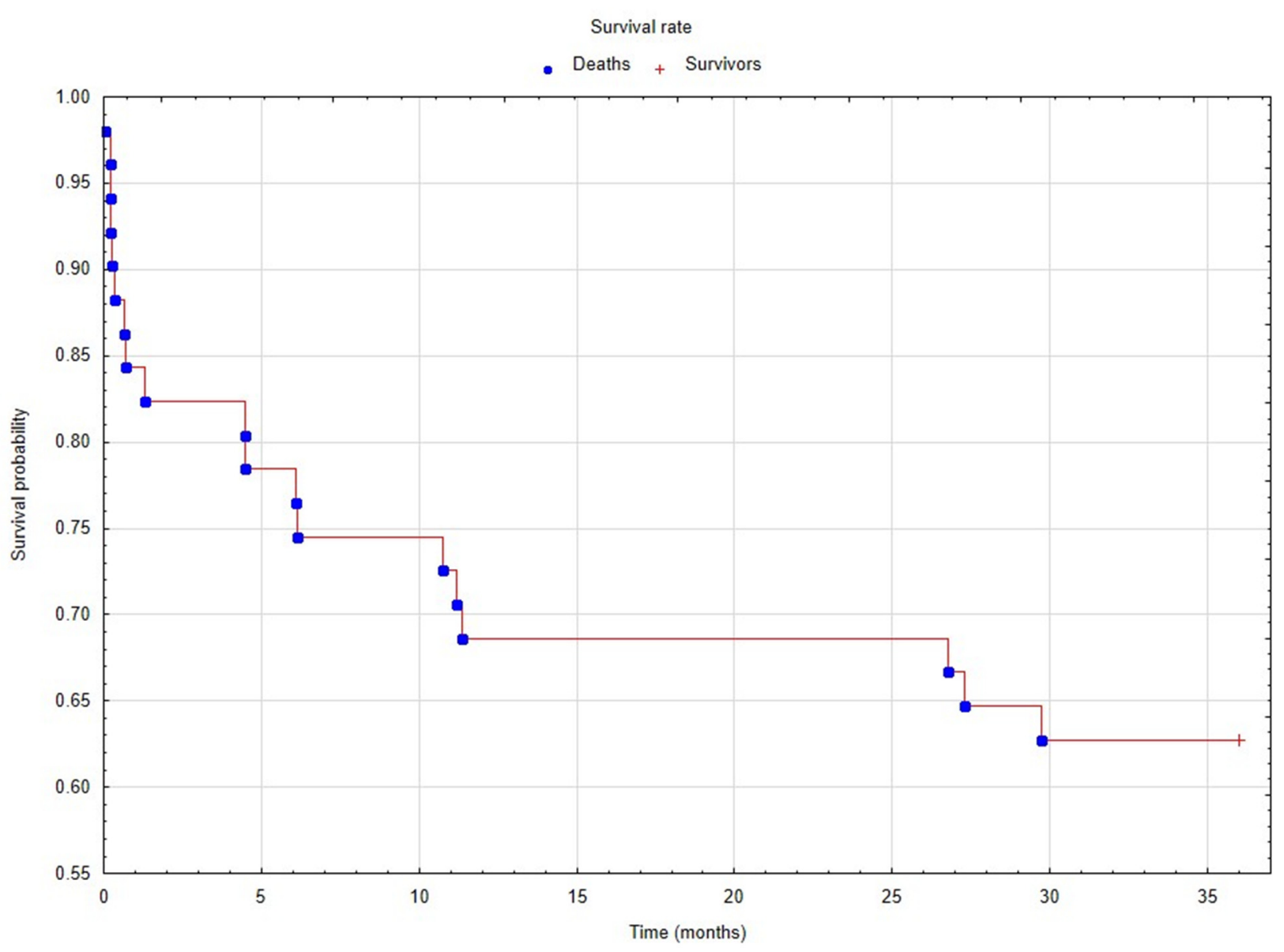

Figure 1. Survival rate in the analyzed population during 36 months of observation. The KaplanMeier estimates were performed to present the survival probability in patients with stroke. The estimated interquartile range for the survival was between 6.13 and 36 months, and survival rate was $62.7 \%$ (blue circle-ischemic stroke patients dead during 36-month observation time; red crossischemic stroke patients survived during 36-month observation time). The SUPAR 1, 3 and 7 concentration for LAO was $3.6 \pm 3.0,3.8 \pm 4.9$ and $4.7 \pm 6.3$ respectively, for lacunar $3.2 \pm 1.1,2.6 \pm 1.3$ and $4.1 \pm 2.0$ respectively, for cardioembolic $3.2 \pm 2.3,3.1 \pm 1.9$ and $3.4 \pm 2.6$ respectively and for ESUS $3.5 \pm 1.5,3.6 \pm 1.9$ and $2.9 \pm 2.0$ respectively. 


\section{Discussion}

Increased concentration of suPAR is associated in the literature with the development, severity, and outcome of diseases, such as sepsis, tuberculosis, cancer, diabetes mellitus or renal disease $[19,25]$. suPAR is proposed as a biomarker of acute and chronic organ damage. It was, however, especially investigated as a biomarker of low-grade inflammation, which is observed in cardiovascular diseases, such as stroke or coronary artery disease (CAD) [32]. It was documented that increased levels of suPAR coincide with endothelium dysfunction, vascular stiffness and worsened cardiac microcirculation or atherosclerosis. Numerous studies investigated its utility as a predictor of outcome or biomarker of severity of stroke, but the results are equivocal. In our study, we assessed if suPAR levels correlate with the outcome of stroke measured in the mRS of disability. We also wanted to investigate if suPAR concentrations are dependent on the stroke subtype in the TOAST classification. Our findings confirm that higher concentrations of suPAR coincide with higher level of disability measured in the mRS.

A few studies investigated potential correlations between suPAR concentration and stroke outcomes. Currently, numerous methods are applied, including imaging, sociodemographic factors and biochemical markers to predict stroke outcome [33,34]. suPAR levels are reported by some authors as being elevated in atherosclerotic etiology of the stroke. Persson et al. reported the relationship between serum SUPAR and the occurrence of carotid plaques and the incidence of stroke and CAD. Patients with high suPAR and carotid plaque had an hazard ratio (HR) of 2.2 (95\% CI 1.5-3.2) for ischemic stroke and HR of 1.7 (95\% CI 1.2-2.4) for CAD [27]. The results of this study are of special importance because of the large study group (5166 people). A study by Edsfeldt et al. reported increased levels of suPAR in plasma and atherosclerotic plaque homogenate of patients with symptomatic LAO due to atherosclerosis, compared to asymptomatic patients [26]. In the present study, it was observed that suPAR concentration fails to differentiate between stroke due to LAO (in all cases caused by symptomatic atherosclerosis) or to other causes. This is partially in line with the findings of Onatsu et al. [29]. The authors reported that although elevated suPAR allows prediction of all-cause mortality due to stroke, it does not differentiate between all stroke types. They reported, however, that patients with stroke due to LAO had a significantly higher suPAR level than those with SVD. In the present study, no correlation was observed between concentrations of suPAR 1,3, and 7 and types of strokes classified according to TOAST classification. This may be explained by the fact that elevated suPAR levels are not specific for atherosclerosis but may also reflect the activation of numerous inflammatory systems. This may be due to the infectious complications of stroke, which are frequent among patients with stroke.

suPAR should also be taken into consideration as a possible prognostic factor of functional disability evaluated with the $\mathrm{mRS}$ and other function outcomes. In the present study, a significant positive correlation between suPAR and the mRS was observed, between suPAR 3 measured on the third day after stroke onset and the mRS 24 months from stroke onset. To the best of our knowledge, while many papers investigated prognostic factors of stroke outcome [35], this is the first study to investigate correlations between suPAR levels in ischemic stroke and the functional outcome of patients with a 3-year long follow-up. suPAR was proposed as a predictor of 5-year all-cause mortality in a study by Onatsu et al. [29] In the present study, such a correlation was not observed. This may be due to a shorter follow-up (3 vs. 5 years) and a smaller patient group (51 vs. 117). Importantly, our study group included much older patients (73.7 vs. 61 years), which may affect mortality [29]. Additionally, it did not include a group of patients with TIA. This may impact the clinical outcome, especially disability. The mean serum level of suPAR in ischemic stroke patients is correlated with the serum level of PCT (inflammatory marker) and NT-proCNP (inflammatory and endothelial damage marker); therefore, it should be taken into consideration as a possible prognostic factor of inflammation and endothelial damage in this group of patients. The main limitation of the study is the size of the group. 


\section{Conclusions}

The authors conclude that suPAR concentration measured after 3 days from stroke onset can be taken into consideration as a possible prognostic factor of functional disability of patients suffering from stroke due to all causes. suPAR fails to differentiate patients with stroke due to different etiologies.

Author Contributions: Conceptualization D.R., D.K. and S.S.; methodology D.R., Ł.M., S.S., M.F. and P.M.; formal analysis S.S., R.T., Ł.M.; investigation D.R., S.S, K.S.; resources D.R., S.S., K.S.; data curation D.R., S.S., K.S., M.F.; writing—original draft preparation, D.R., K.S., M.F, Ł.M.; writingreview and editing, D.R., Ł.M., M.F., K.S., P.M. and D.K.; visualization P.M., Ł.M., M.F.; supervision P.M. and D.K.; project administration: D.R., K.S., M.F.; funding acquisition, D.R., D.K. All authors have read and agreed to the published version of the manuscript.

Funding: Statutory Funds of Department of Neurology, Medical University of Warsaw.

Institutional Review Board Statement: The study was approved by the Ethics Review Board of Medical University of Warsaw (KB/211/2013).

Informed Consent Statement: Informed consent was obtained from all subjects involved in the study.

Data Availability Statement: Data available from the corresponding author on demand.

Conflicts of Interest: The authors declare no conflict of interest.

\section{List of Abbreviations}

$\begin{array}{ll}\text { suPAR } & \text { soluble urokinase plasminogen activator receptor } \\ \text { uPAR } & \text { urokinase plasminogen receptor } \\ \text { mRS } & \text { modified Rankin Scale } \\ \text { CRP } & \text { C-reactive protein } \\ \text { PCT } & \text { procalcitonin } \\ \text { NT-proCNP } & \text { N-terminal pro C-type natriuretic peptide } \\ \text { ELISA } & \text { enzyme-linked immunosorbent assay } \\ \text { CVD } & \text { cardiovascular disease } \\ \text { DM2 } & \text { type 2 diabetes mellitus } \\ \text { CVE } & \text { cardiovascular events } \\ \text { TIA } & \text { transient ischemic attack } \\ \text { SVD } & \text { small vessel disease } \\ \text { CT } & \text { computer tomography scan } \\ \text { MRI } & \text { magnetic resonance imaging } \\ \text { TOAST } & \text { trial of ORG 10172 in acute stroke treatment } \\ \text { ASA } & \text { acetylsalicylic acid } \\ \text { ECG } & \text { electrocardiograph } \\ \text { LAO } & \text { large artery occlusion } \\ \text { ESUS } & \text { embolic stroke of undetermined source } \\ \text { SD } & \text { standard deviation } \\ \text { HbA1C } & \text { glycated hemoglobin } \\ \text { HDL } & \text { high-density lipoprotein } \\ \text { LDL } & \text { low-density lipoprotein } \\ \text { NIHSS } & \text { National Institute of Health Stroke Scale } \\ \text { AF } & \text { atrial fibrillation } \\ \text { LASSO } & \text { least absolute shrinkage and selection operator } \\ & \end{array}$

\section{References}

1. Libby, P.; Ridker, P.M.; Maseri, A. Clinical cardiology: New frontiers. Circulation 2002, 105, 1135-1143. [CrossRef] [PubMed]

2. Hansson, G.K. Inflammation, Atherosclerosis, and Coronary Artery Disease. N. Engl. J. Med. 2005, 352, 1685-1695. [CrossRef]

3. Packard, R.R.; Libby, P. Inflammation in atherosclerosis: From vascular biology to biomarker discovery and risk predic-tion. Clin. Chem. 2008, 54, 24-38. [CrossRef] 
4. $\quad$ Myers, G.; Rifai, N.; Tracy, R.P.; Roberts, W.L.; Alexander, W.; Biassuci, L.M.; Catravas, J.D.; Cole, T.G.; Cooper, G.R.; Khan, B.V.; et al. CDC/AHA Workshop on Markers of Inflammation and Cardiovascular Disease: Application to clinical and public health practice: Report from the laboratory science discussion group. Circulation 2004, 110, e545-e549.

5. Whiteley, W.; Tseng, M.-C.; Sandercock, P. Blood biomarkers in the diagnosis of ischemic stroke: A systematic review. Stroke 2008, 9, 2902-2909. [CrossRef]

6. Thunø, M.; Macho, B.; Eugen-Olsen, J. suPAR: The molecular crystal ball. Dis. Markers 2009, 27, 157-172. [CrossRef]

7. Chavakis, T.; Kanse, S.M.; Yutzy, B.; Lijnen, H.R.; Preissner, K.T. Vitronectin concentrates proteolytic activity on the cell surface and extracellular matrix by trapping soluble urokinase receptor-urokinase complexes. Blood J. Am. Soc. Hematol. 1998, 91, 2305-2312.

8. Estreicher, A.; Muhlhauser, J.; Carpentier, J.-L.; Orci, L.; Vassalli, J.-D. The receptor for urokinase type plasminogen activator polarizes expression of the protease to the leading edge of migrating monocytes and promotes degradation of enzyme inhibitor complexes. J. Cell Biol. 1990, 111, 783-792. [CrossRef] [PubMed]

9. Kirchheimer, J.C.; Nong, Y.H.; Remold, H.G. IFN-gamma, tumor necrosis factor-alpha, and urokinase regulate the expression of urokinase receptors on human monocytes. J. Immunol. 1988, 141, 4229-4234. [PubMed]

10. Nykjaer, A.; Møller, B.; Todd, R.F.; Christensen, T.; Andreasen, P.A.; Gliemann, J.; Petersen, C.M. Urokinase receptor. An activation antigen in human T lymphocytes. J. Immunol. 1994, 152, 505-516. [PubMed]

11. Chen, W.; Jin, W.-Q.; Chen, L.-F.; Williams, T.; Zhu, W.-L.; Fang, Q. Urokinase receptor surface expression regulates monocyte migration and is associated with accelerated atherosclerosis. Int. J. Cardiol. 2012, 161, 103-110. [CrossRef]

12. Li, X.-N.; Varma, V.K.; Parks, J.M.; Benza, R.L.; Koons, J.C.; Grammer, J.R.; Grenett, H.; Tabengwa, E.M.; Booyse, F.M. Thrombin Decreases the Urokinase Receptor and Surface-Localized Fibrinolysis in Cultured Endothelial Cells. Arter. Thromb. Vasc. Biol. 1995, 15, 410-419. [CrossRef] [PubMed]

13. Reuning, U.; Little, S.; Dixon, E.; Bang, N. Effect of thrombin, the thrombin receptor activation peptide, and other mitogens on vascular smooth muscle cell urokinase receptor mRNA levels. Blood 1994, 84, 3700-3708. [CrossRef] [PubMed]

14. Hansson, G.K.; Libby, P. The immune response in atherosclerosis: A double-edged sword. Nat. Rev. Immunol. 2006, 6, 508-519. [CrossRef]

15. Chavakis, T.; Willuweit, A.; Lupu, F.; Preissner, K.; Kanse, S. Release of Soluble Urokinase Receptor from Vascular Cells. Thromb. Haemost. 2001, 86, 686-693. [CrossRef] [PubMed]

16. Fazioli, F.; Resnati, M.; Sidenius, N.; Higashimoto, Y.; Appella, E.; Blasi, F. A urokinase-sensitive region of the human urokinase receptor is responsible for its chemotactic activity. EMBO J. 1997, 16, 7279-7286. [CrossRef] [PubMed]

17. Mandriota, S.J.; Seghezzi, G.; Vassalli, J.-D.; Ferrara, N.; Wasi, S.; Mazzieri, R.; Mignatti, P.; Pepper, M. Vascular Endothelial Growth Factor Increases Urokinase Receptor Expression in Vascular Endothelial Cells. J. Biol. Chem. 1995, 270, 9709-9716. [CrossRef] [PubMed]

18. Pliyev, B.K.; Menshikov, M.Y. Release of the Soluble Urokinase-Type Plasminogen Activator Receptor (suPAR) by Activated Neutrophils in Rheumatoid Arthritis. Inflammation 2010, 33, 1-9. [CrossRef]

19. Wittenhagen, P.; Kronborg, G.; Weis, N.; Nielsen, H.; Obel, N.; Pedersen, S.; Eugen-Olsen, J. The plasma level of soluble urokinase receptor is elevated in patients with Streptococcus pneumoniae bacteraemia and predicts mortality. Clin. Microbiol. Infect. 2004, 10, 409-415. [CrossRef]

20. Eugen-Olsen, J.; Gustafson, P.; Sidenius, N.; Fischer, T.K.; Parner, J.; Aaby, P.; Gomes, V.F.; Lisse, I. The serum level of soluble urokinase receptor is elevated in tuberculosis patients and predicts mortality during treatment: A community study from Guinea-Bissau. Int. J. Tuberc. Lung Dis. 2002, 6, 686-692.

21. Riisbro, R.; Christensen, I.J.; Piironen, T.; Greenall, M.; Larsen, B.; Stephens, R.W.; Han, C.; Høyer-Hansen, G.; Smith, K.; Brünner, N.; et al. Prognostic significance of soluble urokinase plasminogen activator receptor in serum and cytosol of tumor tissue from patients with primary breast cancer. Clin. Cancer Res. 2002, 8, 1132-1141.

22. Stephens, R.W.; Nielsen, H.J.; Christensen, I.J.; Thorlacius-Ussing, O.; Sørensen, S.; Danø, K.; Brünner, N. Plasma urokinase receptor levels in patients with colorectal cancer: Relationship to prognosis. J. Natl. Cancer Inst. 1999, 91, 869-874. [CrossRef]

23. Henić, E.; Borgfeldt, C.; Christensen, I.J.; Casslén, B.; Høyer-Hansen, G. Cleaved Forms of the Urokinase Plasminogen Activator Receptor in Plasma Have Diagnostic Potential and Predict Postoperative Survival in Patients with Ovarian Cancer. Clin. Cancer Res. 2008, 14, 5785-5793. [CrossRef]

24. Piironen, T.; Haese, A.; Huland, H.; Steuber, T.; Christensen, I.J.; Brünner, N.; Danø, K.; Høyer-Hansen, G.; Lilja, H. Enhanced Discrimination of Benign from Malignant Prostatic Disease by Selective Measurements of Cleaved Forms of Urokinase Receptor in Serum. Clin. Chem. 2006, 52, 838-844. [CrossRef]

25. Eugen-Olsen, J.; Andersen, O.; Linneberg, A.; Ladelund, S.; Hansen, T.; Langkilde, A.; Petersen, J.; Pielak, T.; Møller, L.N.; Jeppesen, J.; et al. Circulating soluble urokinase plasminogen activator receptor predicts cancer, cardiovascular disease, diabetes and mortality in the general population. J. Intern. Med. 2010, 268, 296-308. [CrossRef]

26. Edsfeldt, A.; Nitulescu, M.; Grufman, H.; Grönberg, C.; Persson, A.; Nilsson, M.; Persson, M.; Björkbacka, H.; Goncalves, I. Soluble Urokinase Plasminogen Activator Receptor is Associated with Inflammation in the Vulnerable Human Atherosclerotic Plaque. Stroke 2012, 43, 3305-3312. [CrossRef] 
27. Persson, M.; Östling, G.; Smith, G.; Hamrefors, V.; Melander, O.; Hedblad, B.; Engström, G. Soluble urokinase plasminogen activator receptor: A risk factor for carotid plaque, stroke, and coronary artery disease. Stroke 2014, 45, 18-23. [CrossRef] [PubMed]

28. Sehestedt, T.; Lyngbaek, S.; Eugen-Olsen, J.; Jeppesen, J.; Andersen, O.; Hansen, T.W.; Linneberg, A.; Jørgensen, T.; Haugaard, S.B.; Olsen, M.H. Soluble urokinase plasminogen activator receptor is associated with subclinical organ damage and car-diovascular events. Atherosclerosis 2011, 216, 237-243. [CrossRef] [PubMed]

29. Onatsu, J.; Taina, M.; Mustonen, P.; Hedman, M.; Muuronen, A.; Arponen, O.; Korhonen, M.; Jäkälä, P.; Vanninen, R.; Pulkki, K. Soluble Urokinase-type Plasminogen Activator Receptor Predicts All-cause 5-Year Mortality in Ischemic Stroke and TIA. In Vivo 2017, 31, 381-386. [CrossRef] [PubMed]

30. Kiiski, H.; Jalkanen, V.; Ala-Peijari, M.; Hämäläinen, M.; Moilanen, E.; Peltola, J.; Tenhunen, J. Plasma Soluble Urokinase-Type Plasminogen Activator Receptor Is Not Associated with Neurological Outcome in Patients with Aneurysmal Subarachnoid Hemorrhage. Front. Neurol. 2017, 8, 144. [CrossRef] [PubMed]

31. Adams, H.P., Jr.; Bendixen, B.H.; Kappelle, L.J.; Biller, J.; Love, B.B.; Gordon, D.L.; Marsh, E.E., 3rd. Classification of subtype of acute ischemic stroke. Definitions for use in a multicenter clinical trial. TOAST. Trial of Org 10172 in Acute Stroke Treatment. Stroke 1993, 24, 35-41. [CrossRef] [PubMed]

32. Lyngbæk, S.; Sehestedt, T.; Marott, J.L.; Hansen, T.; Olsen, M.H.; Andersen, O.; Linneberg, A.; Madsbad, S.; Haugaard, S.B.; Eugen-Olsen, J.; et al. CRP and suPAR are differently related to anthropometry and subclinical organ damage. Int. J. Cardiol. 2013, 167, 781-785. [CrossRef] [PubMed]

33. Esmael, A.; Elsherief, M.; Eltoukhy, K. Prevalence of cognitive impairment in acute ischaemic stroke and use of Alberta Stroke Programme Early CT Score (ASPECTS) for early prediction of post-stroke cognitive impairment. Neurol. Neurochir. Polska 2021, 55, 179-185. [CrossRef] [PubMed]

34. Leško, N.; Maretta, M.; Škorvánek, M.; Frankovičová, M.; Sihotský, V.; Špak, L.; Gdovinová, Z. Predictors of outcome events and 6-year mortality after carotid endarterectomy and carotid stenting in patients with carotid artery stenosis. Neurol. Neurochir Polska 2021, 55, 67-73. [CrossRef] [PubMed]

35. Desmond, D.W.; Moroney, J.T.; Sano, M.; Stern, Y. Incidence of dementia after ischemic stroke: Results of a longitudinal study. Stroke 2002, 33, 2254-2260. [CrossRef] [PubMed] 